\title{
RAGAM SENI ARCA CANDI BOROBUDUR SEBAGAI SUMBER PEMBELAJARAN SEJARAH
}

\author{
Oleh: Rahman* \\ *Mahasiswa Program Studi Pendidikan Sejarah FKIP Universitas PGRI Palembang
}

\begin{abstract}
ABSTRAK
Makna ragam seni arca candi Borobudur pada hakikatnya tak bisa dipisahkan dari kehidupan manusia yang dibentuk menyerupai manusia, hewan, tumbuhan-tumbuhan. Arca yang berwujudan seorang dewa yang disembah para penganutnya untuk tujuan pemujaan. Adapun rumusan masalah dalam penelitian ini adalah nilai sejarah apakah pada ragam seni arca candi Borobudur yang dapat dimanfaatkan sebagai sumber pembelajaran sejarah dan tujuan penelitian ini adalah untuk mengetahui nilai sejarah ragam arca candi Borobudur yang dapat dimanfaatkan sebagai sumber pembelajaran sejarah. Metode dalam penelitian ini adalah metode deskriptif kualitatif. Teknik pengumpulan data melalui dokumentasi, observasi, dan wawancara. Teknik analisis data yaitu reduksi data, penyajian data dan penerikan kesimpulan. Berdasarkan hasil pembahasan dapat disampaikan bahwa candi Borobudur merupakan suatu banguan yang termegah di Indonesia dan di temukan sekitar abad ke VIII Masehi, sekaligus peninggalan agama Budha terbesar yang terdapat di pulau Jawa.
\end{abstract}

Kata Kunci: Ragama Seni Arca, Candi Borobudur, Sumber Pembelajaran Sejarah.

\section{A. PENDAHULUAN}

Sistem religi sebagai salah satu unsur kebudayaan mengandung tiga wujud kebudayaan yang mengandung ide atau gagasan, aktivitas atau tindakan, dan hasil karya manusia. Dalam sistem religi, tiga wujud kebudayaan ini mempunyai kaitan satu sama lainnya. Sistem religi adalah salah satu dari tujuh kebudayaan yang bersifat universal, dapat ditemukan pada seluru suku di dunia (Rahardjo, 2006:46).

Candi Borobudur adalah mahakarya budaya putra nusantara yang telah diakui dunia. Candi ini berlatar belakang agama Budha tersebar di pulau Jawa. Bila melihat letak candi Borobudur di desa Borobudur, kecamatan Borobudur, kabupaten Magelang, provinsi Jawa Tengah dan secara astronomis berada di 7036 ' 28 " LS $110^{0} 12^{\prime} 13$ "BT. Lingkungan geografis candi Borobudur berada di daerah dataran Kedu yang dikelilingi oleh gunung Merapi dan Merbabu di sebelah Timur, gunung Sindoro dan Sumbing di sebelah utara, dan pegunungan Menoreh di sebelah Selatan. tentu lokasi dipilih berdasarkan pertimbangan Secara simbolis, letak Borobudur yang berdekatan dengan dua sungai, yaitu sungai Elo dan sungai Praga, seolah berorientasi ke dua sungai suci dan indah, Sungai Yamuna dan Sungai Gangga. Di pertemuan kedua sungai tersebut dirikan bangunan-bangunan suci. Candi Borobudur dibangun sekitar 800 M. Namun, sejak dinasti Mataram Hindu memindahkan pusat pemerintahannya dari Jawa Tengah ke Jawa Timur sekitar $930 \mathrm{M}$, tidak ada lagi berita tentang candi Borobudur. Hanya ada berita singkat temuan dalam kitab Nagarakartagama (1365 M) pupuh 77 tentang nama "budur" yang disebut sebagai salah satu tempat suci sekte Vajradhara Buddha. Yang dimaksud dengan "Budur" mungkin Candi Borobudur. Dalam kitab Badad Tanah Jawi disebutkan bahwa sekitar tahun 1710 seorang pemberontakan seorang Ki Mas Dana bersembunyi di Redi Borobudur (Bukit Borobudur) namun akhirnya tertangkap (Rahardjo, 2006:2). 


\section{B. METODE PENELITIAN}

Berdasarkan rumusan masalah, penelitian ini menggunakan metode deskriptif kualitatif. Sumber Data. Informan, Dokumen. Tempat penelitian di candi Borobudur dan SMA PGRI 1 Palembang. Teknik Pengumpulan Data: Wawancara Mendalam, Kajian Dokumen, Observasi Langsung. Teknik Cuplikan. penelitian ini menggunakan teknik cuplikan purposive sampling. Validitas Data. Validitas data sangat penting dalam proses pemaparan hasil penelitian, pembahasan dan penarikan simpulan. Dengan adanya validitas data triangulasi yang digunakan: triangulasi data, triangulasi metode.

\section{HASIL DAN PEMBAHASAN} Hasil Penelitian

\section{Pengarcaan Budha di candi Borobudur}

\section{Budha Bhumisparcamudra}

$$
\text { Budha Bhumisparcamudra. }
$$

Bhumisparsha artinya "menunjuk sebagai saksi", atau "memanggil bumi sebagai saksi". Dalam mudra ini, Budha digambarkan duduk dalam posisi padmasana (posisi duduk seperti bunga teratai) dan tangan kanannya turun melintasi lutut kanan menyentuh tanah. Tangan kiri biasanya dalam posisi dhyana mudral meditasi di pangkuan. Ini adalah gerakan tangan yang merujuk pada sebuah adegan dalam riwayat hidup Budha pencerahan". Mara dibilang perlambangan hawa nafsu, sehingga ada juga yang mengatakan arti mudra ini adalah "melepaskan nafsu duniawi". Mudra ini umumnya ditampilkan di arca Budha Gautama karena terhubung langsung kisah kehidupan beliau (Panyadewa, 2014:94).

Budha kelima menempati zenith, oleh karena itu, arca-arca Dhyani Budha yang terdapat dalam relung pagar langkan tingkat 5 adalah Dhyani Budha Wairocana, sikap tangannya vitarkamudra, yaitu meletakkan ibu jari kanan pada telunjuk, yang mengisyaratkan sikap berbincang-bincang atau memberi pengajar (Prasetyo, 1993:39). Budha Vara Mudra

Vara Mudra (kadang disebut juga vara mudra) berarti "memberikan berkah". Mudra ini dapat dilakukan dengan tangan kanan atau tangan kiri. Dalam arca dengan posisi berdiri, figur berdiri tegak dan tangan yang melakukan mudra tergantung ke bawah dengan telapak tangan terbuka mengarah ke depan. Dia arca dengan posisi duduk, tangan ditekuk dan diletakkan di lutut, telapak tangan terbuka dan mengarah ke depan. Varada mudra berarti "memberikan hadiah", "memberikan berkah", "mengabulkan harapan". Sikap tangan ini melambangkan keinginan Budha dan Bodhisattva untuk bekerja demi keselamatan untuk manusia. Mudra ini melambangkan sifat murah hati, welas asih, dan terkabulnya keinginan. Bodhisattva yang melambangkan sifat welas asih seperti Avalokiteshvara, misalnya, populer digambarkan dengan varada mudra (Panyadewa, 2014:98).

Budha yang terletak pada sisi arah Selatan pagar langkan tingkat 1 sampai 4 ditempatkan Budha Ratnasambhawa. Sikap tangannya Varamudra, yaitu telapak tangan kanan menghadap ke atas diletakkan pada paha kanan, jari-jari menunjuk ke bawah dan tangan kiri diletakkan di pangkuan, mengisyaratkan kedermawanan atau mengabulkan suatu permohon (Prasetyo, 1993: 40).

Bodhisattva lainnya ialah Samantabhradra, figur yang sangat berperan dalam Gandavyuha-Sutra, yang juga telah membuat banyak Mahapranidhana. Di Tibet, Nepal, dan Mongolia, tiada terdapat perubahan wujud seperti itu, barangkali dikarenakan adanya Tara suatu kelompok dari 21 dewi yang berasal Avalokitesvara. Dari 21 Dewi Tara ini yang paling populer adalah White-Tara (Tara Putih) dan Green-Tara (Tara Hijau) (Suwarto, 1995: 399-400). 
Vidyarajah berarti Raja yang dari tubuhnya keluar cahaya yang terangbenderang. (istilah ini digunakan dalam ajaran Esoteric atau rahasia atau yang mementingkan segi batiniah). Vidyarajah mempunyai dua arti, yakni: (a) menunjukkan Dharani, (b) menunjukkan Manifestasi dari Budha Shakyamuni, Yang mempunyai wajah marah untuk maksud mengalahkan mahkluk-makhluk hidup yang jahat. Dalam ajaran Esoteric terdapat Vidyarajah: (1) Vidyarajah-Acalanathah, (2) VidyarajahTrailoka-Vijayah, (3) Vidyarajah-Kundali, (4) Vidyarajah-Yamantaka, (5) Vidyarajah-Vajra Yaksah. Vidyarajah Maha-Mayuri-Rajni atau Vidyarajah yang terdapat dalam Sutra Maha-Mayuri-Vidya-Rajni. Menurut ajaran Esoteric di wilayah Timur, diterangkan bahwa salah satu dari empat kewajiban Dharma yang Dharma yang utama adalah percaya kepada Vidyarajah Maha-MayuriVidya-Rajni. Di Jepang, ajaran esoteric sangat menilai tinggi ajaran beliau, yakni Sekte Yamabusi Ha Sekte Jukendo (jalan untuk membina diri dan untuk menempuh ujian spiritual) (Suwarto, 1995:399-400).

\section{Budha Dhyanamudra}

Budha Amitabha, dengan gelar Budha Yang Bercahaya Tidak Terbatas atau Yang Berkehidupan Tak Terbatas mencapai ke-Budha-an atau samyak-Sambudha atau kesadaran Agungnya pada suatu kalpa yang tidak terhitung. Sukhavativyuha-Sutra (teks panjang) menjelaskan bahwa beliau adalah Budha yang transendental atau di luar pengetahuan dan pengalaman manusia. Budha yang telah mengatasi alam duniawi, dihormati dan dipuji di India, Nepal, Tibet, dan Mongolia sebagai salah satu dari Panca-Dhyani-Budha (terdapat reliefnya di dalam candi Borobudur).

Dhyana artinya meditasi. Dalam mudra ini, Budha digambarkan duduk dalam posisi padmasana dengan kedua tangan berada di pangkuan setinggi perut. Tangan kanan di atas tangan kiri, telapak kedua tangan menghadap ke atas, jari diluruskan, dan ujung jempol kedua tangan bersentuhan. Ini adalah posisi tangan untuk bermeditasi di India bahkan sebelum zaman Budha hidup. Sampai sekarang umat Budha jika bermeditasi masih memposisikan tangan seperti ini. Mudra ini kadang disebut juga samadhi mudra (Panyadewa, 2014:95). Mudra ini melambangkan "kesempurnaan spiritual pencerahan". Mengendalikan pikiran", dan "kestabilan /keseimbangan batin". Tangan kanan melambangkan usaha atau aktivitas, tangan kiri melambangkan kebijaksanaan. Tangan kanan selalu di atas tangan kiri, artinya bahwa usaha dan aktivitas selalu harus didukung oleh kebijaksanaan. Mudra ini dapat dilakukan dengan hanya tangan kiri, sementara tangan kanan melakukan mudra yang lain. Kadang-kadang arca Budha yang melakukan dhyana mudra dengan tangan kiri ini juga membawa mangkuk biksu di tangan kiri (Panyadewa, 2014:96).

Budha yang terletak pada sisi arah Barat. Terletak pada pagar langkan tingkat 1 sampai 4. Sikap tangannya dhyanamudra, yaitu kedua telapak tangan menghadap ke atas, diletakkan di atas pengakuan, mengisyaratkan ketika sang Budha bermeditasi di bawah pohon bodhi (Prasetyo, 1993:41). Meditasi adalah pengembangan batin. Melalui meditasi, batin dan seluruh kehidupan kita bertumbuh secara spiritual-karena kesadaran kita menjadi semakin berkembang.

\section{Budha Abhaya Mudra}

Abhaya artinya "tanpa ketakutan". Dalam mudra ini, tangan kanan diangkat setinggi bahu atau lebih rendah, dengan tangan ditekuk dan telapak tangan mengarah ke luar. Mudra ini sangat populer di semua tradisi Budhis dan dapat ditampilkan di arca yang berdiri, berjalan, atau duduk. Abhaya mudra adalah sebuah sikap tangan yang tua, yang menandakan persahabatan dan perdamaian. Karena mengangkat tangan yang kosong tanpa senjata. Mudra ini menyimbolkan 
perlindungan, tanpa bahaya, rasa aman, tidak rasa takut. Mudra ini juga memberikan rasa tanpa takut itu kepada orang lain, sehingga juga berarti "jangan takut". Ini berhubungan dengan kekuatan spiritual Budha yang sudah bebas dari rasa takut dan dapat memberikan perlindungan dari ketakutan kepada makhluk lain. Selain Budha, figur bodhisattva juga ditampilkan dengan mudra ini (Panyadawe, 2014:9).

Budha yang terletak pada sisi arah Utara diduduki oleh Budha Amoghasidhi, terletak pada pagar langkan tingkat 1 sampai 4. Sikap tangannya abhayamudra, yang berarti jangan takut, dengan telapak tangan kanan terbuka ke atas. Perlu diketahui bahwa sistem Dhyani Budha di candi Borobudur terdiri dari lima Budha, empat Dhyani Budha menduduki empat penjuru mata angin (Prasetyo, 1993:42).

\section{Budha Vitarku Mudra}

Vitarku mudra artinya "menyakinkan", "menjelaskan", "diskusi dharma", dan melambangkan bahwa Budha sedang berkhotbah. Mudra ini dilakukan dengan cara membuka tangan lalu menyentuhkan ibu jari dan jari telunjuk. Ibu jari dan jari telunjuk membentuk lingkaran yang melambangkan kesempurnaan atau pencerahan. Mudra ini digunakan baik di arca yang duduk maupun arca yang berdiri.

Mudra ini juga bisa dilakukan dengan jari selain jari telunjuk misalnya pada arca Bodhisattva Tara yang menyentuhkan ibu jari dengan jari manis. Selain itu, pertemuan ibu jari dan jari lain juga tangan yang digunakan untuk memegang suatu objek sehingga kadang tangan yang melakukan varada mudra memegang sesuatu. Misalnya Bodhisattva Manjushri yang memegang tangkai bunga teratai di tangan kiri dalam vitarka mudra (Panyadewa, 2014:99).

Budha pagar langkan kelima terdapat Budha dengan sikap tangan dharmacakramudra, yang mengisyaratkan pergerakan roda dharma (ajaran), yaitu sikap tangan yang menggambarkan waktu sang Budha pertama kali memberikan kotbah. Semua arca di dalam stupa berlubang pada teras melingkar tingkat 1 sampai 10 mempunyai sikap tangan dharmacakramudra. Sedangkan sebuah arca yang tersembunyi di dalam stupa induk berada sikap bhumisparcamudra (Prasetyo, 1993:44).

\section{Zenith Budha}

Khotbah Hyang Budha Shakyamuni yang pertama kali kepada lima pertapa bekas teman sewaktu bertapa menyiksa diri di hutan Uruval selama enam tahun lamanya. Khotbah pertama laki ini di taman Rusa Isipatana, di Mrigadava, Veranasi, atau dikenal dengan nama pemutaran Roda Dharma (Dharmacakra Pravartana Sutra) yakni mengenai 4 (delapan) Julan Utama atau jalan benar dan suci sebagai jalan tengah (Arya Astangika Marga).

\section{Arca Manusia yang Perwujudan Dewa \\ Para Dewa Pelindung Dharma; Para} Dewa Dharmapala; Dewa Deva, Dewa Naga, Dewa Yaksa, Dewa Gandharva, Dewa Asura, Garuda, Dewa kinnara, dan Mahoraga. Catur-Maharaja (empat Raja Dewa; adalah panglima wilayah luar Alam Dewa Indra dan sebut Lokapala atau pelindung Alam Dunia, masing-masing Dewa melindung satu Dvipa atau dunia).

a. Dewa Dhrtarasta: pelindung benua Timur (Pura-Videha). Warna putih. Panglima dengan anak buahnya terdiri dari Gandharva dan Pisacah.

b. Dewa Virudhaka: Pelindung benua Selatan (Jambudvipa). Warna biru. Panglima yang anak buahnya terdiri dari Kumbhanda dan Preta.

c. Dewa Virupaka: Pelindungan benua Barat (Apara-Godanya). Warna Merah. Panglima yang anak buahnya terdiri dari Naga dan Putana

d. Dewa Vaisravana: (Dhanada), disebut pula kuvera atau kubera. Pelindung benua Utara (kuru). Warna kuning 
Dewa Rejeki. Panglima yang anak buahnya terdiri dari Yaksa dan Raksasa.

\section{Dewa Skandha; Senapati Dewa Skanda/Skandha (Dewa Dharma pala). Dewa Sangharamapala}

a. Tubuh dan mukanya berwarna hitam, wajahnya seram menakutkan, tangan kanan mengacungkan gada berduri dan tangan kirinya memegang ular. Ada yang tubuh dan wajahnya dicat dengan warna kuning emas atau dilapasi kertas kuning emas yang tipis, dengan maksud mengurangi keseraman wajahnya.

b. Kuan Tie Kun (Hok Mo Tay TeeKuan Se Tie Kun-Tay Pie Guan-Tay Sin Tay Cu-Cin Guan Hian Hien Ciau Beng le Han Tay Thian Cun). Dewa pelindung Dharma.

c. Dewa-dewa vimsati Deva (ada 20 Dewa), Caturvismsati Deva (ada 24 Dewa), Dvadasa Deva (sete Mantrayana; sekte Shingon; ada 12 Deva), Vimsat vajradeva (20 Vajra Deva), Vidya Raja (lebih dari 10 Raja), Jambhala (dewa Rejeki), Mahakala (Bermata tiga bertangan empat), Danda Mahakal, Dakini, Mahasri atau Sri Maha Devi (Dewi keberuntungan), Vajrapani atau Vajradhara, Heruka, Kumaraka Deva, Nata (Putra sulung Vaisravana), Nirvisi, Atri Kurukula, Uma, Vajrakirna, Guhya Samaya, Cakra Samvara, dan Nava Kumara Aryamatr (Deva Puspa dan Devi Puspa).

\section{Bhumya Deva atau Bhumya Devata (Dewa Bumi)}

Dalam sutra-sutra Mahayana, yaitu Ksitigarbha Bodhisattva Purva Pranidhana Sutra, Buddhavacana Maitreya Bodhisattva Abhisambuddha Sutra, Maha Karuna Dharani Sutra, disebutkan bahwa banyak Dewa, Naga, dan Setan yang hadir mendengarkan khorbah Shakyamuni Budha tentang Sutra-sutra tersebut, antara lain: Dewa Samudra, Dewa Bumi, Dewa Siang Hari, Dewa Tumbuhan-tumbuhan, Dewa Rumah, Dewa Kota, Dewa Api, Dewa Angin, Dewa Sungai, Dewa Padi-padian, Dewa Malam Hari, Dewa Tumbuhan-tumbuhan Obat, Dewa istana, Dewa Air, Dewa Tanah, Dewa Batu, Raja Setan Pertengkaran, Raja Setan Kejahatan, Raja Setan Berhati Kasih Sayang, Raja Setan Yang Memiliki Rejeki Dan Bahagia, Raja Setan Macam Putih, Raja Setan Macan Darah, dan Raja Setan Pengurus Nyawa. Di antara Raja Setan itu sebenarnya bukan setan melainkan makhluk mulia yang memperlihatkan diri atau menjelma sebagai Raja Setan. Banyak Preta atau Setan yang 'berhasil' atau bahagia pada hakekatnya adalah Yaksa atau Maharddhika. Raja Setan pada hakekatnya adalah Raja Yaksa.

Raja Naga (ada Raja Naga), Dasa Raksasi (10 Raksasa Perempuan), Dvadasa Mahayaksa Senapatyah (12 Senopati Yaksa). Setiap Senopati Yaksa mempunyai 7000 Yaksa sebagai anak buahnya. 12 Senopati Yaksa ini menjadi 'pelindung Dharma' sebagaimana dijelaskan dalam Bhaisajyaguru Vaiduryaprabhasa Tathagata Purva Pranidhana Sutra. Beliau mengucapkan 12 Nalar Besar. Bagi siapa saja yang menyebut nama Bhaisajyaguru Vaiduryaprab Tathagata, orang yang menghormati dan memberi puja kepadanya, orang yang membaca Sutra tersebut atau membaca mantranya akan dikabulkan oleh mereka 12 Senopati Yaksa; Kumbhira, Mihara, Anila, Indra, Mahoraga, Catura, Vajra, Andira, Sandila, Pajra, Kinnara, dan Vikarala.

Dewa-dewa lainnya dan makhluk lain (amanusya; manusyamanusya) yang muliaPratima-pratima lain (Manusya) Nagarjuna: orang India, yang hidup pada pertengahan abad ke 2. Pendiri Sekte Mahyamaka Agama Budha Mahayana. Beliau disebutsebut juga sebagai the Second Founder of Budhism. Filsafat Agama Budha yang dirintis oleh Nagarjuna merupakan pusat 
doktrin Sunyata dari semua konsep empiris, seperti Dharma, atau unsur pokok yang terakhir mengenai eksistensi, ditegaskan di dalam Abhidharma. Nagarjuna dengan ajaran Prajnaparamita yang begitu mendalam. Beliau dianggap salah satu genius spiritual terbesar dan pemikir yang paling brilian di dunia yang pernah ada.

\section{Arca Budha yang dihubungkan dengan Agama Budha}

Permulaan Agama Budha menanamkan ide rangkap mengenai arhatva (PI. arahatta) dan nirvana (PI. nibbana).

\section{Makara}

Makara adalah hewan mitologis yang hidup setengah di air dan setengah di darat berdasarkan cerita India; candi sering kali digambarkan dengan singa kecil yang berdiri di mulutnya yang terbuka. makara adalah kendaran Dewi Hindu Gangga dan lambang Dewa Hindu Kamadeva dan dewadewi Hindu lainnya. Kuil Hindu dan Budha di India maupun di kawasan lain yang menerima pengaruh budaya India sering kali mempunyai Makara sebagai dekorasi. Makara sebagai lambang kerajaan Dinasti Syailendra dari Prasasti Nagapattana di abad ke-11 (Panyadewa, 2014:53).

\section{Singa}

Menurut agama Budha singa adalah kendaraan Sang Budha pada awal waktu naik ke surga dan simbol kekuatan pengusir pengaruh jahat untuk menjaga kesucian candi (Balai Konservasi, 2016:43). Arca singa digambarkan dalam posisi duduk dengan kedua kaki depan lurus, dan kaki belakang dilipat. Adapun surai singa berupa hiasan simbolik berupa sulur-suluran yang mengitari bagian kepala sampai ke leher singa dalam hal ini digambarkan dalam posisi duduk, kedua kaki belakangnya dilipat, sementara kaki depan tegak. Bagian belakang tubuh singa telah aus dan tidak terdapat adanya indikasi penggambaran ekor. Singa arca yang berukuran lebih kecil duduk di atas lapik yang sama dengan arca singa yang berukuran lebih besar (Depdikbud, 2012:13-14).

\section{Durga Mahisasuramardani}

Arca Dewi Durga sebagai istri Siwa. Digambarkan durga berdiri di atas banteng Nandi yang sudah dikalahkan. Banteng tersebut sebetulnya adalah makhluk jahat yang menyamar dan sesudah dikalahkan makhluk jahat tersebut ditarik dari badan banteng, lalu menunjukkan sifat yang sesungguhnya. Durga adalah Dewi Kematian, oleh karena itu ditempatkan di kamar yang menghadap ke utara dan merupakan mata angin kematian. Patung Durga ini maksud menggambarkan permaisuri raja Balitung (Soetarno, 1987: 19). Patung Durga oleh penduduk di sekitarnya juga disebut patung Lara Jonggrang. Disebut Jonggrang, itu menurut Legenda penduduk Prambanan yang akhirnya berkembang menjadi cerita rakyat.

\section{Kala}

Kala adalah hiasan berupa kepala raksasa yang digambarkan dengan mata melotot dengan hiasan stilir (disamarkan). Kala melambangkan waktu, maut, dan hitam. Dalam arsitektur candi biasanya diletakkan pada bagian atas pintu masuk atau ambang atas tangga candi. Kala dapa digambarkan dengan rahang bawah atau tanpa rahang bawah dengan ukiran tangan seperti akan menerkam. Kala pada doorpel (ambang atas pintu masuk) pada candi borobudur digambarkan tanpa rahang bawah. Selain pada ambang atas pintu tangga candi, kala pada candi Borobudur juga digunakan sebagai jaladwara (saluran air) (Balai Konservasi, 2016:43). 
Jaladwara

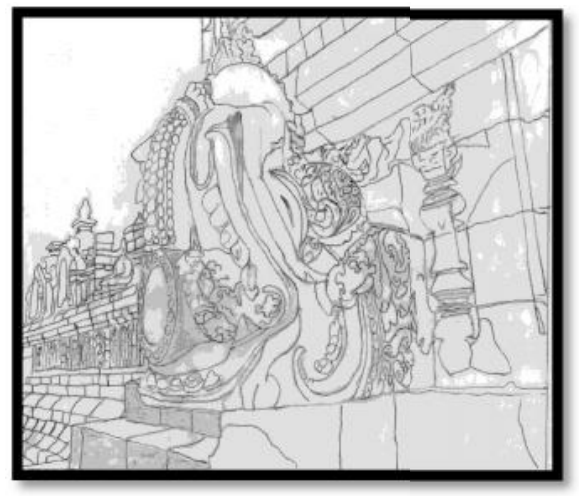

Dokumentasi Rahman Talang Ubi

Di beberapa tempat di sepanjang dinding luar langkan terdapat jaladwara atau saluran untuk membuang air dari selasar. Jaladwara terdapat di kebanyakan candi di Jawa Tengah dan Yogyakarta Jaladwara di candi Mendut lebih ramping dan lebih kecil dibandingkan dengan Jaladwara dengan Jaladwara pada candi Borobudur (Depdikbud, 2014:38).

\section{Pembahasan}

\section{Nilai Sejarah Ragam Seni Candi Borobudur Sebagai Sumber Pembelajaran Sejarah di SMA PGRI 1 Palembang.}

Dalam arsitektur tradisonal Hindu, ruang, waktu, dan zat adalah manifestasi dari pencipta, ruang kebendaan dan zat kebendaan menjadikan ruang ideasional terlihat: model kosmologisnya menekankan pada: (1) Kemurnian ritual di dalam rona; (2) Pusat dan keterpusatan hal terpenting secara sosial dan secara arsitektur; dan (3) Ruang ideasional yang diejawantahkan melalui lambang-lambang. Ruang diubah oleh lambang-lambang dan ritual-ritual sehingga sifat kedewaan jadi terlihat dan arsitektur disebut 'Wastu Vidya' ilmu persemayaman para dewa selain itu ragam seni hias bisa dijadikan sumber pembelajaran sejarah.

Sedangkan keberadaan candi Borobudur sangat relevan dengan materi yang tercantum dalam kurikulum terbaru yaitu K13 di mata pelajaran sejarah kelas $X$ semester ganjil adapun untuk lebih jelasnya sebagai berikut:

Kompetensi Inti: 3. Memahami, menerapkan dan menganalisis pengetahuan faktual, konseptual, prosedural berdasarkan rasa ingin tahunya tentang ilmu pengetahuan, teknologi, seni, budaya dan humaniora wawasan kemanusiaan, kebangsaan, kenegaraan, dan peradaban terkait fenomena dan kejadian, serta menerapkan pengetahuan prosedural pada bidang kajian yang spesifik sesuai bakat dan minatnya untuk memecahkan masalah.

Kompentensi Dasar 3.6. menganalisis karakteristik kehidupan masyarakat, pemerintahan dan kebudayaan pada masa kerajaan-kerajaan Hindu-Budha di Indonesia dan menunjukan contoh bukti-bukti yang masih berlaku pada kehidupan masyarakat Indonesia masa kini.

Materi: teori-teori masuk dan berkembangnya Hindu-Budha kerajaankerajaan Hindu-Budha Bukti- bukti kehidupan pengaruh Hindu-Budha yang masih ada pada saat ini.

Kendala guru yang di hadapi pada saat mengajarkan sejarah pada siswa ialah minat belajar yang kurang dikarenakan sering menggunakan HP atau gedjet dari pada belajar, biar siswa tertarik dalam belajar sejarah gurunya juga harus kreatif contohnya membuat pembelajaran memakai media infokus dan gambar-gambar biar anak tertarik untuk belajar sejarah (hasil catatan wawancara Bapak Amiril Mukminin, S.Pd pada tanggal 08 Mei jam 09.30 WIB).

\section{SIMPULAN}

Setelah melakukan penelitian dan pembahasan tentang ragam seni arca candi Borobudur sebagai sumber pembelajaran sejarah, maka penulis dapat menyimpulkan hasil penelitian sebagai berikut: Makna ragam seni arca candi Borobudur pada hakikatnya tak bisa dipisahkan dari kehidupan manusia. yang dibentuk menyerupai manusia, hewan, tumbuhan- 
tumbuhan. Arca yang berwujudan seorang dewa yang disembah para penganutnya untuk tujuan pemujaan. Oleh karena itu masyarakat setempat mendirikan sebuah bangunan suci yang disebut candi untuk tempat sembyang yang merupakan tempat dihormati para penganut agama Budha.

Nilai sejarah ragam arca candi

Borobudur yang dapat dimanfaatkan sebagai sumber pembelajaran sejarah. Dalam pembelajaran sejarah memberikan pengetahuan sejarah (kognitif) tetapi juga memperkenalkan nilai-nilai luhur bangsa (apektif). Ini akan memiliki arti penting bagi kehidupan peserta didik pada masa sekarang dan pada masa yang akan mendatang, apabila peserta didik tidak mampu memahaminya. Mengingat setiap peserta didik memiliki kemampuan yang tidak sama untuk menangkap makna yang ada dibalik cerita sejarah, maka setiap pengajar sejerah selalu menekankan pada arti dan makna dari setiap peristiwa yang yang dipelajari.

\section{DAFTAR PUSTAKA}

Balai Konservasi Borobudur. 2016. Kearsitekturan Candi Borobudur. Magelang: Balai Konservasi Borobudur.

Depdikbud. 2012. Pasca Pemugaran Candi Borobudur. Magelang: Balai Koservasi Borobudur.

Panyadewa, Seno. 2014. Misteri Borobudur. Jakarta: Dolphin.

Prasetyo, Bambang. 1993. Borobudur, Pawon dan Mendut. Yogyakarta: KANISIUS.

Rahardjo, Supratikno. 2011. Peradaban Jawa dari Mataram Kuno sampai Majapahit Akhir. Jakarta: Yayasan Kertagama dan Komunitas Bambu.

Suwarto. 1995. Budha Dharma Mahayana. Palembang: Majelis Agama Budha Mahayana. 